\title{
Bir Tasavvufî Terâcim-i Ahvâl Müiellifi İmamzâde Salih Sâim (Unar) ve Terâcim-i Ahvâl-i Evliyâ'sı
}

\author{
YUSUF TURAN GÜNAYDIN \\ Doktora Öğrencisi, ANKARA Ü. SBE İslâm Tarihi ve Sanatları (Türk İslâm Edebiyatı) \\ e-mail: ytgunaydin@yahoo.com
}

\begin{abstract}
A Sufic Biographier İmamzada Salih Saim (Unar) and His Work Called the Teracim-i Ahval-i Avliya (Biographies of Sufis). Imamzada Salih Saim (Unar) is a man of letters who lived in between 1867-1965 in Istanbul. His work called the Teracim-i Ahvâl-i Avliya implies sufi biographies. This working is about the life of Imamzada Salih Saim, his books and Teracim's transcription.
\end{abstract}

\section{key words}

İmamzada Salih Saim (Unar), Teracim-i Ahval-i Avliya, Literature of the Turkish, Biographies of sufis.

Osmanlıca matbu kitaplarında "İmamzâde Sâlih Sâim" imzasını kullanan Salih Sâim Unar 1284/1867'de ${ }^{1}$ İstanbul'da Gümüşsuyu'nda doğdu. ${ }^{2}$ Babası ilmiyeden Hafız Hüseyin Efendi, annesi Hafize Ayşe Hanım'dır. Mediha, Mükerrem ve Şair Ali Rıdvan Unar (1900-1976)'ın³ babası, yayıncı Mit-

1 Emekli Sandığı Arşivi, Askerî Tasnif (NT): 18496.

2 Cemal Kutay, Sebilden Bir Avuç Su/Zamanımızın En Yaşlı Fikir, Siir, Nesir Üstadı Salih Saim Unar'nn Doksan Dört Yillık Mâneviyat ve Edebiyat Hazinesinden Mütevazı Derlemeler, Yeni Savaş Matbaası, İstanbul, 1960, s. 7. Türk Dili ve Edebiyatı Ansiklopedisi (c. VII)'nde "Salih Saim" maddesi bulunmakla birlikte bu madde okuyucuyu "Unar, Salih Sâim" maddesine göndermekte fakat son ciltte yer alan U harfi bölümünde söz konusu madde yer almamaktadır.

3 A. R. Unar'ın Biyografisi için bkz. İbnülemin Mahmud Kemal İnal, Son Asır Türk Şairleri-IV, Millî Eğitim Bakanlığı Yayınları, İstanbul, 1969, s. 1413-1474 (İbnülemin, Sâlih Sâim’i eserine almamışsa da oğlu Ali Rıdvan Unar'a ayırdığı bölümde Sâlih Sâim'den de bir cümleyle söz etmiştir. Bkz. a.g.e.-IV, s. 1473); Murad Uraz, Türk Edip ve Şairleri-3. Kısım, İstanbul, 1940, s. 154-155.Urazburada doğum tarihini 1902 olarak veriyor. A. R. Unar'la ilgili bir hatıra için bkz. Abdullah Satoğlu, "Dr. Ali Rıdvan Unar", Edebiyat Dünyamızdan Hoş Sedâlar, Akçağ Yayınları, Ankara, 2004, s. 65-67. Unar’ın bu kaynaklarda söz edilmeyen bir şiir kitabı Kubbe- 
hat Sadullah Sander'in amcasıdır. ${ }^{4} 21$ Kasım 1965'te İstanbul'da öldü. Kabri Edirnekapı Şehitliğindedir. ${ }^{5}$

Tahsili

İlk tahsilini anne ve babasından aldı. Peşinden Tophane Feyziye Mektebini bitirdi. Arapçayı babasından ve Nusretiye Camiinde "ulûm-ı Arabiyye" tedris eden Huzûr-1 Hümâyun mukarrirlerinden Kazasker Tophaneli Hoca Haşim Efendi'den öğrendi. Döneminin meşhur simalarından Abdülmecid Şirvânî'den Farsça dersleri aldı. ${ }^{6}$

\section{Meslek Hayatı}

İlk vazifesi, "Memûrîn ve Ketebe-i Aklâm-1 Askeriyye ve sâir Mensûbîn-i Cünûdiyyeye Tahsîs Olunan Tekâüd ve Eytâm ve Erâmil Maâşına Mahsûs Hesâb Müzekkeresi"ne göre 1 Ağustos 1299/1883'te ${ }^{7} 16$ yaşındayken başladı̆̆ı Tophâne-i Âmire Rûznamçe Kalemi Harcırâh ve Tedkîk-i Hisâbât memurluğudur. Daha sonra yine burada Muhassesât-1 Zâtiye Evrâk, Riyâset ve Mâruzat, Topçu Dâiresi Yoklama ve Kuyûdât, Mekteb-i Harbiye'de tahrîrât, Sihhiye Dâiresi Birinci Şubede istihbârat ve Şûrâ-yı Askerîde Mühimme ve Muâmelât işlerinde görev yapmıştır. ${ }^{8}$ 1908'de ilga edildikten sonra Îmâlât-1 Harbiye Müdîriyyet-i Umûmiyyesi adını alan Tophâne Harbiye Nezâreti Müşîriyetinden ${ }^{9} 2$ Aralık 1339/1923'te emekli olmuştur. ${ }^{10}$ 1323/1907'de Karadeniz Ereğlisi'nde bulunduğu sırada kendisine "rütbe-i sâniye sınıf-1

de Bâkî Kalan adını taşımaktadır (Ajans-Türk Matbaacılık, Ankara, 1970). Mektep Şiirleri (Yeni Tarih Dünyası Yayınları, İstanbul, 1954) adlı kitabı daha sonra Okul Şiirleri adıyla da basılmıştır (Ersa Matbaacılık, İstanbul, 1963). Tıp doktoru olan şairin Dirim dergisinde yayınlanmış meslekî makaleleri de vardır.

4 Uraz, a.g.e., s. 154; Kutay, a.g.e., s. 7-8. Salih Saim'le ilgili Sander'in Ali Rıdvan Unar'la birlikte hazırladığ İstanbul, 1954.

5 Ölüm ilânı: Cumhuriyet, 21.11.1965. Üsküdar adlı bir eserinin olduğu, oğlu Ali Rıdvan Unar’ın İbnülemin'de biyografisinin bulunduğu bilgilerinden sonra Sâlih Sâim hakkında ilk ulaştığım bilgi bu oldu. Bu bilgileri Prof. Dr. Ali Birinci Hocamıza borçluyum ve kendisine müteşekkirim. Uraz'ın kitabındaki ilgili bölümün fotokopisini gönderen İsmail Kasap'a da bu katkısından dolayı teşekkür ederim.

6 Kutay, s. 8.

7 Emekli Sandığı Arşivi, Askerî Tasnif (NT): 18496.

8 Mithat Sadullah Sander, "Pek Değerli Üstadımız Salih Saim Unar'ın Hâl Tercümesi”, a.g.e., s. 6-10; Kutay, a.g.e., s. 15-20.

9 Tophane Müşiriyeti için bkz. M. Zeki Pakalın, Osmanlı Tarih Deyimleri ve Terimleri Sözlüğ̈̈-III, Millî Eğitim Bakanlı̆̆ı Yayınları, İstanbul, 1993, s. 514-515.

10 Emekli Sandığı Arşivi, Askerî Tasnif (NT): 18496. Emeklilik tarihini diğer kaynaklar da vermektedir. Bkz. Sander, Unar, s. 7; Kutay, s. 17; Uraz, s. 154. 
mütemâyizliği" tevcih edilmiştir. ${ }^{11}$ Mensûbîn-i askeriyeye mahsûs tekâüd maâşı hesap cetvelinde emekliye ayrıldığında rütbesinin "Ketebe-i Askeriyyeden Kısm-1 Sânî Mümeyyizi” olduğu kayıtlıdır. Fakat Salih Sâim'in Maliye Vekâletine verdiği bir dilekçeden anlaşıldığına göre İstanbul Muhassesât-1 Zâtiyye İdâresince tanzim edilen 572726 esas ve 2738 muamele numaralı 12 Nisan 340 (1924) heyet ve mûcibince tekâüd maaşı "Kısm-1 Sâlis Mümeyyizi" rütbesi üzerinden hesaplanmıştır. Salih Sâim dilekçesinde bu durumun düzeltilmesini isteyerek şöyle demektedir: "(...) tam 40 senelik hayât1 resmiyyemde nasılsa "Kısm-1 Evvel Mümeyyizliği”"ni elde etmiş iken garîb ve hayret bir cilve-i tâli' ile son terfîimin 336 (1920) senesine müsâdefetinden dolayı umûm meyânında bir derece tenzîl-i sınıfa uğramıştım. Şu hâlde resmiyetin bana tevcîh edeceği sıfat-ı hizmet ve memuriyet -velev mütekâid de olsam- bieyyi-hâlin "Kısm-1 Sânî Mümeyyizliği"dir. İstanbul Muhassesât1 Zâtiyyesine keyfiyeti ifade ve beyân eylemekliğime mukâbil; "Ankara'dan gelen sened-i resmîde o yolda yazılmıştır, biz de ona göre tanzîm eyledik. Tashîh ve buraya iş'ârını oraya yazmalısınız!...” cevâbı dermeyân edildi ki, pek haklı bulduğum şu tecvîb-i resmîyi işte makâm-ı saâdetlerinize bildiriyorum. Maâşımın da sehven Kısm-1 Sâlis Mümeyyizliği maâşı üzerinden hesâb edildiği takdîrde mağdûriyyetim bihakkın tezâhür eder ki, bu da bilhâssa cây-1 teemmüldür ve dikkat-i nazarı câlibdir."

Sâlih Sâim'in bu dilekçesinin altına memurlar tarafından düşülen kayıtlarda adı ve unvânı "Üsküdar Ahz-i Asker Şubesinde müsâfir Kısm-ı Sâlis Mümeyyizi Sâlih Sâim Bey" şeklinde geçmektedir. Ayrıca burada verilen adresinde "Üsküdar'da Vâlide-Atik Câmi-i Şerîfi karşısında" oturduğunu öğreniyoruz. Salih Sâim'in düzeltilmesini istediği bu "Kısm-1 Sâlis Mümeyyizliği" rütbesi hakkında bir dizi yazışma yapıldığını yine belgeler göstermektedir. Bunun sonucunda 22 Haziran 341 (1925) tarihli T.C. Müdafaa-i Milliye Vekâleti Muâmelât-1 Zâtiye Dairesi Mütekâidîn Şubesinden yazılan yazıda maaşının evvelâ 1750 kuruş olarak hesaplandığı belirtilmiş, bu durumun düzeltilerek rütbesinin "Kısm-1 Sânî Mümeyyizliğine" tahsîs ettirilmesi" istenmiş, böylece Salih Sâim dilekçesinin sonucunu almıştır.

Sâlih Sâim 1 Ağustos 1299/1883 ile 2 Aralık 1339/1923 tarihleri arasında ifa ettiği 40 yıl, 2 ay ve 1 günlük meslek hayatını yaş haddi dolayısıyla yahut hizmet müddetini gösteren belgenin ifadesiyle "25 Ağustos 339 (1923) Tarihli Kanunun 113. maddesi mûcibince" doldurup 1263 kuruş tekaüd maaşıyla emekliye ayrılmıştır. ${ }^{12}$

11 Bu tevcihle ilgili Fuad Hulûsî Demirelli'nin manzum bir tebriki için bkz. Kutay, s. 14.

12 “Müddet-i Hizmeti”ni gösteren belge, Emekli Sandığı Arşivi, Askerî Tasnif (NT): 18496. 
Emekli olduktan sonra aynı yıl Tefeyyüz Kitaphanesi sahibi tarafından yapılan teklifi kabul ederek 1339 Temmuzunda bu müessesenin müdürlügüne geçmiş ve bu işi 1927'ye kadar sürdürmüştür. ${ }^{13}$ Bu tarihten itibaren ise çok sevdiği İstanbul'un "bedî̀ manzaralarını tavaf etmek maksadıyla bu emsalsiz şehrin bin bir köşesini dinî bir pırlanta ihtişamiyle süsleyen camileri ve mescitleri dolaşarak girânbahâ İslâm abidelerinde tetkikler yaparak" vaktini değerlendiren Sâlih Sâim, rahatsızlı̆̆g sebebiyle ömrünün son günlerini evinde geçirmiştir. ${ }^{14}$

\section{Edebî Yönü}

Sâlih Sâim Unar, İbnülemin'in deyişiyle "Memleketin irfânına hizmeti sebkeden erbâb-1 kalemin kıdemlilerinden"dir. ${ }^{15}$ Cemal Kutay da hakkında hazırladığı kitabının alt başlığında "Zamanımızın En Yaşlı Fikir, Şiir, Nesir Üstadı" tavsifini kullanmıştır.

Servet-i Fünûn dergisinin kurucusu Ahmed İhsan Tokgöz (1868-1942)'le Tophane Harbiye Nezaretinde mesai arkadaşı olan Sâlih Sâim, onun çıkardığ 1 ilk dergi olan Umran (1887)'a katkıda bulunmuş, edebiyata hevesli bir genç olarak Ahmed İhsan'la birlikte bu yayının dizgisine kadar ilgilenmiştir. ${ }^{16}$

Hafızasının kuvvetiyle anılan Sâlih Sâim'in edebî müktesebâtı çok genişti. Divanı 1937'deki yangında yanan şair Üsküdarlı Talat'ın bir beyti bile bulunamadığı için İbrahim Alâettin Gövsa'nın Meşhur Adamlar Ansiklopedisi'ndeki Üsküdarlı Talât maddesine şiirlerinden örnekler alınamamışken, yangından 23 sene sonra bir sohbetinde bu şairin birçok beytini hafızasından nakledebilmiştir. ${ }^{17}$

13 Sander'in verdiği bu bilgiler için bkz. Sander-Unar, s. 8; Kutay, s. 18.

14 Bkz. Sander, Unar, s. 9; Kutay, s. 18. Ev adresi Emekli Sandığın belgelerinde "Üsküdar'da Valide Atik Camii Şerifi karşısında sâkin” ifadeleriyle verilmektedir. Bkz. Askerî Tasnif (NT): 18496. Aynı adres, Servet-i Fünûn'un kuruluşunun 75. yıldönümü dolayısıyla yazılan imzasız bir yazıda şöyle belirtilmektedir: "Üsküdar, Atik Valde, No. 56." Bkz. "Yaşıyan Hatıra”, Tarih Konuşuyar, c. III, Mart 1965, S. 14, s. 1150.

15 İbnülemin, IV, 1473.

16 Kutay, Sâlih Sâim'le Ahmed İhsan arasında geçen bir muhavereyi naklediyor. Bkz. a.g.e., s. 8. Buna rağmen Ahmed İhsan, Servet-i Fünûn hatıralarında Sâlih Sâim'den hiç söz etmemiştir. Bkz. Ahmed İhsan Tokgöz, Matbuat Hatıralarım, Hazırlayan: Alpay Kabacalı, İletişim Yayınları, 1. baskı, İstanbul, 1993. Bunun sebebi, genellikle yazıldığının aksine Salih Saim'in Ahmed İhsan'la Servet-i Fünûn döneminde değil, Umran ve Şafak döneminde mesai arkadaşı olması olmalıdır. Ahmed İhsan bu dönemde Tophane Müşiriyyetinden gazetecilik ile memurluk arasında kesin tercih yapması teklifiyle karşılaşınca birinciyi tercih etmiştir. Bkz. Orhan Koloğlu, "Tokgöz, Ahmet İhsan", Yapıtları ve Yaşamlarıyla Osmanlılar Ansiklopedisi-II, Yapı Kredi Yayınları, İstanbul, 1999, s. 625.

17 Bkz. Kutay, s. 3-4. 
Sâlih Sâim'in edebî mektupları da vardır. Çok mektup yazar ve kendisine de çok mektup gelirdi. 1959'da gözleri görmez oluncaya dek mektup yazmayı sürdürmüsstür. Bir gözü tamamen görmez ve diğeri de ancak onda bir görme kabiliyetine sahip olduğu hâlde yine de okuyup yazmayı bırakmamıştır. ${ }^{18}$ Bir kitap dostu olan Sâlih Sâim'in zengin bir kitaplı̆̆ı vardı. Çok okumakla beraber yazardı da. En çok yazı yayınladığı dergilerin Maârif ve Saâdet dergileri olduğu söylenmesine ${ }^{19}$ rağmen bu yayınlar üzerinde yaptığımız incelemede Sâlih Sâim'in makalelerine rastlayamadık. ${ }^{20}$

\section{Edebî ve Tasarvufî Çevresi}

Evi sürekli ziyaretçilerle dolup taşan Sâlih Sâim'in gittikçe genişleyen edebî bir çevresi olmuştur. Her Cuma günü çoğunlukla evinde, bazen de dönemin şairlerinden Halil Edib Bey (1863-1912)'in ${ }^{21}$ Bakırköy'deki evinde toplanılır; Sander'in deyimiyle bu toplantılar "edebî bir encümen" mahiyeti arzeder, herkes yazdıklarını okur, takdir ve tenkitlerle değerlendirmeler yapılırdı. ${ }^{22}$

Tefeyyüz Kitaphanesi müdürlüğü yaparken Kitaphanenin Babıâli yokuşuna nâzır idarehanesindeki odası "bir ilmî mahfel" ve "edebî bir akademi”"23 hâline gelen Sâlih Sâim geniş bir edebî-tasavvufî çevreye sahipti. Süleyman Nazif (1870-1927), Hakkı Süha Gezgin (1895-1963)24, Tokadîzâde Şekip (1871-1932) ${ }^{25}$, Fuat Hulûsî Demirelli (1877-1955) ${ }^{26}$, Üsküdarlı şair Ahmed Talat (1858-1926), İzmirli Şair Ali Şefik (?), kimyager ve şâir Hüseyin Rifat (Işıl, 1878-?) ${ }^{27}$ gibi edebiyatçıların yanı sıra o zamanlar Üs-

18 Kutay, s. 14. BuradaFuat Hulûsî’ye ve Mithat Sadullah Sander'e yazdı̆̆ı iki mektup bulunmaktadır. Sâlih Sâim'in tüm mektuplarının derlenmesi edebiyat ve yakın dönem tasavvuf tarihi açısından gereklidir.

19 Bkz. Sander, Unar, s. 10; Kutay, s. 18-19.

20 Maarif dergisinin Ali Birinci'nin kütüphanesinde bulunan ilk cildiyle Millî Kütüphanede mikrofilmi bulunan diğer ciltlerinde Salih Sâim imzalı yazılara rastlayamadık. Millî Kütüphanede bulunan Saâdet adlı süreli yayın ise bir dergi değil bir gazetedir ve içinde yine Salih Sâim imzalı bir yaziya rastlanmaz.

21 Biyografisi için bkz. İbnülemin, I, 410-414.

22 Bkz. Sander, Unar, s. 10; Kutay, s. 19-20.

23 Sander'e ait bunitelemelerin yer aldığı yazı için bkz. Sander, Unar, s. 9-10; Kutay, s. 18.

24 Bkz. Behçet Necatigil, Edebiyatımızda İsimler Sözlüğü, Varlık Yayınları, İstanbul 1985, s. 146.

25 Bkz. Necatigil, a.g.e., s. 326.

26 İbnülemin Mahmud Kemal İnal, Son Asır Türk Şairleri, c. I, Atatürk Kültür Merkezi Başkanlığ1 Yayınları, Ankara 1999, s. 667-670; Feyzi Halıcı, Parlâmenter Şairler, TBMM Kültür, Sanat ve Yayın Kurulu Yayınları, Ankara, 1990, s. 80-81. Bu kaynaklarda sadece doğum tarihi verilmektedir. Ölüm tarihi ve bir şiir kitabının tanıtımı için bkz. Veli Recai Velibeyoğlu, Şiir Kitapları Antolojisi-II, İstanbul, 1975, s. 1036.

27 Hüseyen Rifat Işl'’n biyografisi için bkz. İbnülemin, IV, 1930-1933. 
küdar Mevlevîhânesi şeyhi olan Remzi Dede (Ahmed Remzi Akyürek: 1872 1944) ${ }^{28}$, Tâhirü'l-Mevlevî (Olgun: 1877-1951) ve İstanbul'daki ilk büyük Mevlevîhane olan ${ }^{29}$ Kulekapisı Mevlevîhânesi postnişîni Celâleddin Efendi (?) gibi tasavvuf erbâbı bu kitaphanedeki odasına sık sık uğrarlardı. Bu isimleri sayan Mithat Sadullah Sander şu değerlendirmeyi yapmaktadır: "Onun cevval zekâsı, güzel ve güler yüzü, mütevazı odasında öyle bir pertev-i câzibedar teşkîl etmişti ki, devrin en sayılı erbab-1 edebi o civara yolları düştükçe bu hücre-i irfana uğramadan geçemezlerdi." ${ }^{30}$

Çevresindeki tasavvuf erbabının genellikle Mevlevî olması, Sâlih Sâim'in de Mevlevî olabileceğini akla getiriyorsa da ulaşabildiğimiz kaynaklar onun tasavvufî yönü hakkında hiçbir bilgi vermemektedir. Eserlerini tanıtırken de görülebileceği gibi 15 eserinin çoğu tasavvufî terâcim-i ahvâle dairdir ve bunlardan biri de Mevlânâ ve Şems-i Tebrîzî̀yi konu almaktadır. Bu eser, diğerlerinden bir farklılık gösterir: Eserlerinde çok kısa bir şekilde birçok sûfîden menkıbeler aktaran Sâlih Sâim, Mevlânâ ile ilgili eserinin tümünü bu mutasavvıfa ve Şems-i Tebrîzîye ayırmıştır. Bu da onun Mevlevîliğe daha yakın olduğuna dair bir ipucu sayılabilir.

Üsküdar'da yaşayan, tasavvuf çevreleriyle irtibatı bulunan ve tasavvufî terâcim yazan bir müellifin Üsküdar'a dair yazılan son hatırat kitaplarında adının geçmediğini belirtmeliyiz. Özellikle Ahmed Yüksel Özemre'nin Üsküdar'ın tasavvuf çevrelerinden söz ettiği eserlerinde ${ }^{31}$ Salih Sâim'in adı geçmez. Bunun sebebi de Üsküdar'ın birbirinden farklı birçok tasavvufî çevreyi bünyesinde barındırması olmalıdır.

\section{Eserleri}

Tasavvufî terâcim-i ahvâle dâir eserleri, ilki hariç sadece bir sûfînin adını taşımakla birlikte her birinin içinde birçok sûfîden çok kısa çizgilerle bahsedilmektedir. Müellifin, ilk sırada yer alan sûfînin adını kitabına verdiğini görüyoruz. Basılış itibariyle ilk eseri olan Terâcim-i Ahvâl-i Evliyâ, aslında bu tür eserlerinin hepsinin ortak adı hükmündedir. Bâyezid-i Bistâmî adlı ese-

28 Akyürek hakkında bkz. Ahmet Cahid Haksever, Son Dönem Osmanlı Mevlevîlerinden Ahmet Remzi Akyürek, T.C. Kültür Bakanlığı Yay., Ankara, 2002.

29 Şeyh Gâlib de Galata Mevlevîhanesi olarak da adlandırılan bu Mevlevîhanede şeyhlik yapmıştır. Bkz. Sezai Küçük, Mevlevîliğin Son Yüzyılı, Simurg Yayınları, İstanbul, 2003, s. 79-88.

30 Bkz. Sander, Unar, s. 8, Kutay, s. 18.

31 Bkz. Özemre, Üsküdar'da Bir Attar Dükkânı, Kubbealtı Neşriyatı, İstanbul, 1997; Geçmiş Zaman Olur ki..., Kubbealtı Neşriyatı, İstanbul, 1998; Portreler, Hâtıralar..., Kubbealtı Neşriyatı, İstanbul, 2001; Üsküdar, Ah Üsküdar!, Kaknüs Yayınları, İstanbul, 2002; Üsküdar'ın Üç Strlısı, Kubbealtı Neşriyatı, İstanbul, 2004. 
rinin sunuşunda belirttiğine göre bu kitabının çok ilgi görmesi; 1000 adet bastırdığı Terâcim'in tükenmiş olması Müellifi yeni kitaplar hazırlama konusunda teşvik etmiştir. Bundan duyduğu memnuniyeti dile getiren Müellif, ayrıca kitapçılarda dolaşırken gözünün önünde kitaplarının sorulup satıldığını belirtmektedir. Terâcim'i yeniden bastırmaktansa bu ilk kitabındaki tercüme-i hâllerden birçoğunu da yeni kitaplarına serpiştirerek her birinin "yeni baştan bir Fâtiha ile ervâh-1 şerîfesi şâd ve kendileri rahmet ve mağfiretle yâd olunur"32 düşüncesiyle yeni kitaplar hazırlamıştır. Hazırladığı bu tür kitaplarında Nefehâtü'l-Üns'ü kaynak olarak kullanmıştır.

Aslında İmâmzâde Sâlih Sâim'in, bir bütünün parçaları sayılabilecek tasavvufî tercüme-i hâllere yer veren tek formalık küçük kitapları, ilk kitabının adıyla (Terâcim-i Ahvâl-i Evliyâ) ve tercüme-i hâli tekrar edilenler ayıklanarak tek kitap hâlinde basılabilir. Böylece müellifin edebî yönden kuvvetli bir üslûpla kaleme aldığı bu eserleri bir arada tasavvuf okuyucusunun dikkat nazarlarına sunulabilir. Böyle bir girişim, Bâyezîd-i Bistâmî adlı eserinden yukarıda iktibas ettiğimiz ifadesiyle, bu kez kendi ruhu da "Bir Fâtiha-i Şerîfe ile şâd ve rahmet ve mağfiretle yâd edilmek" bakımından güzel olacaktır.

\section{Tasavvufî Terâcim-i Ahvâle Dâir Eserleri}

1. Terâcim-i Ahvâl-i Evliyâ, Kasbar Matbaası, İstanbul, 1307, 29 s.

2. İmâm-ı A'zam ve Eimme-i Selâse, Bâbıâlî Caddesinde 25 Numaralı Matbaa, İstanbul, 1314, 24 s. (İlk baskı); Bâbıâlî Caddesinde 38 Numaralı Matbaa, İstanbul, 1317/1901, 24 s. (2. bask1).

3. Hüccetü'l-İslâm İmâm Gazâlî, Şirket-i Mürettibiyye Matbaası, İstanbul, 1315, $22 \mathrm{~s}$. $18 \mathrm{s.}^{33}$

4. Bâyezîd-i Bistâmî, Şirket-i Mürettibiyye Matbaası, İstanbul, 1315,

5. Muhyiddin-i Arabî ve sâir Bâzı Efâhim-i İslâmiye, Şirket-i Mürettibiyye Matbaas1, İstanbul, 1315, $18 \mathrm{s.}$

6. Emir Buhârî, Âlem Matbaas1, İstanbul, 1315, $20 \mathrm{s.}$

7. Mevlânâ Celâleddîn-i Rûmî ve Şemseddîn-i Tebrîzî, Mahmud Bey Matbaas1, İstanbul, 1317/1901 (İkinci baskı), $22 \mathrm{~s}$.

8. Muhadderât-ı Evliyâ, Asır Matbaası, İstanbul, 1317/1901, 24 s.

32 Bkz. İmâmzâde Sâlih Sâim, Bâyezîd-i Bistâmî, Şirket-i Mürettibiyye Matbaası, İstanbul, 1315, s. 2-3.

33 Eserin çevrimyazısı için bkz. Yusuf Turan Günaydın, "İmâm-zâde Sâlih Sâim’in Tasavvuf Târîhine Dâir Eseril-II", Özlenen Fark, S. 37-38, Ağustos-Eylül 1999, s. 22. 
Hikem Tarzı Eserleri (Edebî Seçmeler ve Ahlâkî-Tasavvufî Hikmetler) ve Mektupları:

1. Cümel-i Hikemiyye, Kasbar Matbaası, İstanbul, 1306, 20 s.

2. Altın Küpe ve Mecmûa-i Nesâyih, Âlem Matbaası, İstanbul, 1308/1892, $30 \mathrm{~s}$.

3. Mahfûzât-ı Edebiyye, Kasbar Matbaası, İstanbul, 1318, $40+1$ s. ${ }^{34}$

4. Ana Baba Nasîhatleri, Kasbar Matbaası, İstanbul 1307/1890, 14 s. ${ }^{35}$

5. Mürâselât, Tophâne-i Âmire Matbaas1, İstanbul 1306/1889, 23 s. ${ }^{36}$

Hâtırat Türü Eserleri:

1. Üsküdar - Şaşı Hâfız ve Mâruf Nüktedanlar, Tefeyyüz Kitaphânesi, Kültür Matbaası, İstanbul, 1941, 24 s. $^{37}$

2. Hâttraları: Sâlih Sâim'in ziyaretçilerinden olan ve hakkında bir derleme hazırlayan Cemal Kutay, Sâlih Sâim Unar'ın hatıralarını kaleme aldığını; "Hatıralarını, kendisinden sonraki nesilde, hayatın en basit görülen safhalarının bile, derinliğine inebilmiş engin dimağlarda nasıl berceste tesbitler olabileceğinin ölmez misâli olarak gün gün kaydeden Üstad (...)" ${ }^{38}$ diyerek belirtmekte ve Müellifin Kastamonu yolculuğuna dair bir bölümünü de iktibas etmekteyse de, bu hâtırat basılmamıştır. Yayınlanması yakın dönem edebiyat ve tasavvuf tarihine 1şık tutacaktır. ${ }^{39}$

\section{Metin}

Terâcim-i Ahvâl-i Evliyâ Sâlih Sâim'in yayınlanmış ilk eseridir. Bu eserinde yer verdiği sûfîlere daha sonra basılan eserlerinde de serpiştirilmiş olarak rastliyoruz. Görünen o ki İmâmzâde, diğer eserlerini de bu ilk eserini model alarak telif etmiştir. Bâyezîd-i Bistamî adlı eserinin önsözünde de ilk eserinden söz etmekte ve çok ilgi gördüğünü vurgulamaktadır. Bu sebeplerin yanı sıra söz konusu eserlerinin muhtevasını ve telif metodunu yansıtması açısından bu metni seçtik.

34 Sâlih Sâim bu eserinde kendisini "câmî ve muharrir" olarak nitelemiștir.

35 A.g.CD (Özege: 744). Son iki eseri Millî Kütüphanede bulunmamaktadır.

36 Bkz. Eski Harfli Türkçe Basma Eserler Bibliyografyası (Arap, Ermeni ve Yunan Alfabeleriyle) 1584-1986, Millî Kütüphane yayını CD (Özege: 14910).

37 Latin harfleryle matbu olan bu eserin Prof. Dr. Ali Birinci'deki nüshasının son sayfasında Arap harfleriyle ve el yazısıyla "Okadar takayyüdâta ve mükerrer tashîhâta rağmen, mürettiblerce yine beş on yerde imlâ ve terkîb hatâları vukûa getirilmiştir. İtizâr olunur.” notu vardır. Yayıncılıkla da uğraşan ve Cemal Kutay'ın ifadesine göre (a.g.e., s. 10) okuduğu her kitabın "hayırhah niyet ve babacan eda ile"tashihini de yapma itiyadına sahip olan Müellifin bu notu, kitabının bir hediye nüshasına veya belki de bütün nüshalarına yazmış olabileceği hatıra geliyor.

38 Kutay, s. 10.

39 Sâlih Sâim'in hatıraları konusunda kendisine vefatından önce internet sitesi (www.cemalkutay.com) aracılığıyla ulaşmaya çalıştı̆̆ımız Cemal Kutay’dan herhangi bir cevap alamadık. 
Metin, verdiği bilgiler açısından değil dili ve terâcim-i ahvâl yazımında kullandığı popüler diyebileceğimiz üslûbu açısından dikkat çekicidir. Yazarın döneminin okur yazar kesimine kolay okunan tasavvufî terâcim-i ahval kitapçıkları sunmayı hedeflediğini söyleyebiliriz. Dili ise Servet-i Fünûn dönemi edebiyatçılarının kullandığı Türkçeye yakındır.

Burada metne, verdiği bilgiler açısından yaklaşmıyoruz, çünkü bu bilgilerin bir kısmı bugün eskimiş ve tartışılabilir durumdadır. Bu hususlara dipnotlarda yeri geldikçe işaret ettik. Orijinal metnin sayfa numaralarını köşeli parantez içinde gösterdik. Metinde geçen Hicrî tarihleri Milâdî tarihe çevirerek parantez içinde belirttik. Metin içinde Türkçeye tercüme edilmemiş Arapça ve Farsça ifadeleri tercüme ederek dipnotlarda verdik. Yazımda hafifletilmiş bir transkripsiyon kullandık.

TERÂCIM-I AHVÂL-i EVLIYÂA ${ }^{40}$

\section{[3] MUKADDIME-IFTITÂH}

Cenâb-1 Hakk'a çok şükür.

Sâye-i meâlî-vâye-i Hazret-i Pâdişâhîde Kütübhâne-i Osmâniyye vü İslâmiyyemize bir eser daha vaz' u ilhâk ile hisse-yâb-1 fahr ü sürûr oldum. Bu eser-i fakîrânemin de az bir zamânda mevki'-i enzâr ü intişâra vaz'1 mahzâ erbâb-1 iktidâr u maârifin teşvîkât-1 terakkî-cûyâne ve himem-perverâneleri eseridir.

Evet! "Emr-i teşvîk"in âdetâ bir "emr-i hayr" makâmında telâkkîsine her sâhib-i vicdân kâil olabilir. Matbûât-1 Osmâniyemiz tarafından görülen bu teşvîkât-1 mütevâliye ve âciz-nüvâzâne bugün hemen her eline kalem alanları kâğıt üzerinde yürütmeğe cesâret-yâb etmektedir. Ne âlî-cenâbâne bir himmet, ne terakkî-küsterâne bir gayret!..

Hele âsâr-1 matbûanın ciddiyyâta âid ve sahîhen menâfi'-i umûmiyyeye müsâid olanları hakkında edilen idâre-i kelâm u efkâr ise o misillü eserlerin muharrir ve mütercimlerini -muvaffakiyetlerinden dolay1- el-hak şükrân-1 azîm ile karışık bir meserrete gark etmekte ve onu müteâkib bir eser-i nâfi' daha vücûda getirmek için şiddetli bir ârzû ve ikdâma mağlûb, mecbûr eylemektedir.

Ezcümle, neşriyât-1 evveliye-i âcizânemin bir ikisi evlâd-ı vatanın [4] tehzîb-i ahlâk ve tenvîr-i efkârına hâdim olmak ve içindeki nesâyih-i pederâne

40 Künyesini ilgili yerde verdiğimiz bu kitapçı̆̆ın kapağında şu ifadeler vardır: "Pîşüvân-ı erbâb-1 tarîkat ve muktediyân-1 râh-1 hakîkat olan evliyâ-yı izâm hazerâtından ba'zılarının câlib-i hayret ve mûcib-i ibret ve herkesçe bâdî-i imtisâl ü riâyet olacak efâl ve ahvâl ve menâkıb-1 âlü’l-âllerini şâmildir. / Fiyatı 4 paradır. / Maârif Nezâret-i Celîlesinin ruhsatiyle tab' olunmuştur." 
ve hayr-hvâhâne ile âdetâ bir "mürebbî-i etfâl" sıfatında bulunmak hasebiyle ashâb-1 âdâbdan bâzı zevât ile cihet-i matbûâttan -me'mûlün fevkinderağbet ve kütübhâne-i millîmizde kendilerine münâsib bir mahal görmüş, âcizleri de teşvîkât-1 lutf-kârî terakkî-sâzîye mahzar buyurulmuş idi.

İşte bu sebeble evvelki cesâretim gereği gibi kesb-i kuvvet eylediğinden şu eseri vücûda getirmeğe -Hamden li'llâhi Teâlâ- muvaffak oldum. Bu kitâb, isminden de anlaşıldığı üzere evliyâ-yı izâm efendilerimizden bâzılarının ahvâl ü kerâmât-sâdire ve vâkıalarının tercemesidir.

Binâen-aleyh, o hâllerle hem-hâl olmağa, o kerâmetleri ihrâz ve ihzâr etmeğe, hîç olmazsa 1slâh-1 ahvâl ve ahlâk ile dâreynini îmâr eylemeğe gayretli bir muâvin bulunduğu için neşrini münâsib gördüm. Ve mina'llâhi'ttevfîk.

$$
\text { İbtidâ-yı Recebü'l-Ferd } 307 \text { Cuma }
$$

Kabataş

\section{[5] TERÂCIM-i AHVÂL-i EVLIYÂ}

İbrâhîm Edhem Kaddesa'llâhu sirrehû

Müşârün-ileyh, tabaka-i ûlâdandır. Künyesi Ebû İshâk'tır. Nesebi İbrâhîm b. Edhem b. Süleymân b. Mansûr el-Belhî’dir. Ebnâ-i mülûktandır. Genç iken terk-i mâl ü câh etmiştir.

Bir gün sayde çıkmıştı. Hâtiften bir sadâ, hemân gûş-1 intibâhına vâsıl oldu. O sadâ "Yâ İbrâhîm! Seni bu iş için halketmemişlerdir." cümlesinden ibâret idi. Bu tenbîh-i hâtifâne, kendisine o kadar te'sîr etti ki; gönlü gözü açılıp muhkem tarîkate yapıştı. Ve Mekke-i Mükerreme cânib-i şeref-câline azm-i râh ile o makâm-1 mübârekte Süfyân-1 Servî ve Fudayl b. Iyaz ve Ebû Yûsuf Gusûlî hazerâtiyle sohbet eyledi. Ba'dehû Şâm-1 Şerîfe gidip bir kâr u kesb ile meşgûl olmak niyetinde bulunarak taleb-i helâl için nâturluk etti. Ya'nî bă̆ bekçisi oldu.

Tarîkatte çok kelâmı vardır. Kendisi kerâmet ehlinden idi. Hicretin 166'sında (M. 783) ${ }^{41}$ terk-i bağçe-i hayât ve azm-i ravza-i cennât eylemiştir.

\section{Seriyy-i Sakatî Kuddise sirruhu'l- 'âlî}

Tabaka-i ûlâdandır. Künyesi Ebü'l-Hüseyn'dir. Cüneyd-i Bağdâdî [6] ve sâir Bağdâdîlerin üstâdıdır. Hâris-i Muhâsibî, Bişr-i Hafî akrânındandır. Ma'rûf-i Kerhî’nin şâkirdidir. Kendisine çok kişinin nisbeti vardır.

41 Kesin olmamakla birlikte 161/778 olmalıdır. Bkz. Reşat Öngören, “íbrâhim b. Edhem”, DİA, XXI, 293. 
Cüneyd-i Bağdâdî hazretleri demiştir ki: "Ben Serî'den ziyâde ibâdet ehli görmedim. Yetmiş sene hîçbir kimse onu yanı üstüne yatar görmedi. Ancak hâl-i mevtte görebilirler."

Ve yine Cüneyd-i müşârün-ileyh buyurmuştur ki: "Bir gün Serînnin hânesine gittim. Gördüm ki, hânesini süpürüyor; hem bu beyti okuyup ağlıyordu. Beyt:

Lâ fi'n-nehâri ve lâ fi'l-leyli lî ferec

Fe lâ-ubâlî etâle'lleyle em kasar. ${ }^{42}$

Dîğer:

Ne şeb tehîm ne rûz ez nâle vü âh

$H^{v} a ̂ h \hat{~ s ̧ e b ~ m e n ~ d i r a ̂ z ~ u ~ h v a ̂ h i ̂ ~ k u ̂ t a ̂ h . ~}$

Tercümesi:

Çü rûz u şeb işim oldu cihânda nâle vü âh

Bana ne geceler olsa dirâz yâ kûtâh.

Şu "Bidâyetü'l-ma'rifeti tecrîdü'n-nefs li't-tefrîdi li'l-Hakk." "33 kelâm-1 âlî, Hazret-i Serî'nindir. Yânî "Ma'rifetin evveli mahzâ Cenâb-1 Hakk'1 murâd edinip nefsi mâ-sivâdan pâk eylemektir."

Hicretin 253. senesi (M. 867) Ramazân-1 şerîfin bir gününde ale's-seher imsâk-1 hayât ile azîm-i dâr-1 berîn olmuştur.

Bâyezîd-i Bistâmî Kaddesa'llâhu Te'âlâ sirrehu's-sâmî

Müşârün ileyhin ismi Tayfûr b. Îsâ b. Âdem'dir. Vefâtına [7] karîb bir zamânda "Benim kabrimi hâacemin dahmesinden aşağı bulundurunuz!" (Üstâdına hürmet için) demiştir. Üstâdı bir Kürd idi. ${ }^{4}$

Rivâyet edilir ki; Bistâmî Hazretleri her ne zamân namâz kılsa herkes göğsünün kemiklerinin ka'ka'asını yânî âvâz-çıtırtısını işitirlerdi. Bu hâl, Hak Teâlâ'nın heybet ve azameti ve şerîat-1 Ahmediyyeye olan hürmeti eclden idi. Zamân-ı vefâtını hissedince; "İlâhî mâ zekertüke illâ 'an gafletin ve mâ hademtüke illâ 'an fitretin." ${ }^{45}$ dedi. Şu yolda tercüme edildi: "Yâ Rab hergiz seni yâd etmedim; meğer gafletle ve sana ibâdet etmedim, meğer fitretle!" Böyle deyip teslîm-i rûh eyledi.

Ebû Mûsâ, Hazret-i Bâyezîd'in şâkirdi idi. Bâyezîd, Hak Teâlâ'yı rüyâsında görüp "Yâ Rab! Sana nasıl yol olur?" diye suâl eyledi. Cenâb-1 Bârî ve Tekaddes dahi "Vücûdundan geçenler bana erişir." buyurdu.

42 "Gündüz ve geceleyin bana rahat yoktur.Gecenin uzaması da kısalması da umurumda değil." 43 "Ma'rifetin başı tefrîd sebebiyle Hakk için nefsin soyutlanmasıdır."

44 Süleyman Uludă̆, Bistamî’nin 100 küsur üstaddan istifade etmiş olmakla birlikte asıl olarak Ebû Ali es-Sindî adlı bir sufîyi üstad edindiğini belirtir. Bkz. Süleyman Uludağ, "Bâyezid-i Bistâmî", DİA, V, 238-239.

45 "Allahım, seni gafletten uzak bir şekilde zikredemedim ve sana uyuşukluktan başka bir tavırla hizmet edemedim." 
Bâyezîd vefât ettikten sonra vâkıada görüp "Hâlin ne oldu?" diye sordular. Cevâben; "Bana 'Ey pîr! Buraya ne getirdin?' dediler. Ben de 'Bir dervîş bir pâdişâhın kapısına gelince ona ne getirdin demezler. Belki ne istersin derler.' dedim." buyurmuştur.

Müşârün-ileyh Hicretin 261. senesinde (M. 875) ${ }^{46}$ tekmîl-i hayât-1 müsteâr ile reh-rev-i bârgâh-1 dârü'l-karâr olmuştur.

\section{Ebû Sâbit er-Râzî Kaddesa'llâhu rûhahû}

Müşârün-ileyh ulemâ, fukarâ, kurrânın meşhûrlarından idi. Bir gün bir mescide oturmuş, bir oğlancığa Kur'ân-1 Kerîm ta'lîm eylemekte idi. Yûsuf b. Hüseyn nâmında bir zât-1 sâhib-i kerâmât o aralık mescid-i şerîfe duhûl ile "Utanmaz mısın ki bir muhannese Kur'ân Ta'lîm eylersin!" dedi. Sâbit Hazretleri kalbinden "Subhâna'llâh, bir cennetlik oğlancığa böyle dedi" dedi. Çok geçmedi, o çocuğu muhanneslerle hem-bezm-i ülfet gördüler.

\section{Meymûn el-Mağribî Kaddesa'llâhu Te'âlâ sirrehû}

Müşârün-ileyh Mağrib kavmindendir. Seyâhat ehlinden idi. Meşâyıhın kudemâsından idi. Ebû Mâsâ-yı Deybelî̀ye seferde yoldaş olmuş idi. Âyât ve kerâmât ıssı idi. Çehre-i mübâreki siyâh idi.Her gâh semâ eylerdi. Kendisinin bir dağarcığı vardı ki; cânı her ne istese içinden elini sokup o nesneyi çıkarırdı.

\section{Ebû Bek el-Vâsıtî Kuddise sirruhû}

İsm-i âlîleri Muhammed b. Mûsâ'dır. Meşâyıh-ı kavmin âlimlerinden idi. Hîç kimse usûl-i tasavvufta onun gibi söz söylememiştir. Usûle ve ulûm-1 zâhireye âgâh idi. Horasan'da Vâsıtî̀nin zebânından sâdır olan tevhîd gibi[si] hîçbir kimsenin lisânından sâdır olmamıştır.

Hicret'in 320'sinde (M. 932) Merv'de bi'l-irtihâl vâs1-1 rahmet ve âzim-i cennet olmuştur.

\section{Ebü'l-Abbâs Seyyârî Kaddesa'llâhu sirre-hu'l-âlî}

İsm-i şerîfi Kâsım b. Kâsım el-Mehdî'dir. Ahmed b. Seyyâr'ın hemşîrezâdesidir. Ehl-i Merv'dendir ve onların şeyhidir. Hakâyık-ı ahvâle âlim ve fakîh idi. Mübârek hâtırında pek çok hadîs-i şerîfler vardı. Peder-i vâlâ-güherinden hadden efzûn mîrâs kalmıştı. Cümlesini verip Peygamber-i Zî-şânımız, sebeb-i duhûl-i [10] cinânımız efendimiz hazretlerinin mû-yi saâdetlerinden iki tel-i mübârek satın aldı. Hak celle ve alâ (Azze şânuhû) ol mûyı hôş-bû-yi risâletin berekâtiyle şeyh-i müşârün-ileyhe tevbe müyesser oldu. 
Ve Ebû Bekir Vâsıtî’nin sohbetine mahzar olduğu gibi mutasavvifeden bir sınıfın imâmı olmak ile dahi kadr ü menzileti i'lâ edildi.

Vefâtına yakın ettiği vasiyet üzerine mezkûr mû-yi saâdeti ba'de’l-vefât ağzına koydular. Merv'de medfûndur. Kâffe-i nâs -ki ora ahâlîsi- kabrini ziyaret eder ve diledikleri hâcete mazhar olurlar. Cenâb-1 Kâsım tevhîdi; "Hâtıra Hak Teâlâ'dan gayri bir şey gelmeye" ile tefsîr buyurmuşlardır.

Hicret'in 342'sinde (M. 953) rahmet-i Rahmân'a karîn ve füyûzât-1 gufrâna rehîn olmuştur.

\section{Ebü'I-Kâsım el-Hakîm es-Semerkandî Kaddesa'llâhu Teâlâ sirrehû}

İsm-i mübârekleri İshak b. Muhammed b. İsmâîl'dir. Vasf-1 şerîflerinde demişlerdir ki; "Ebu Kâsımarştan toprağa varınca Hak Teâlâ'nın gayriye nazar etmezdi." Halk ile muâmele ve mükâlemesi kendisinin değil, onların hazzı ve hâtırlarının hoş olması için idi. Ebû Bekir Verrâk hazretleri ile hemsohbet idi.

[11] Hicret'in 342'sinde (M. 953) Muharremin onuncu (Yevm-i Âşûrâ) günü irtihâl-i dâr-1 âhiret eylemiştir.

\section{Gaylân el-Mevsûs Kaddesa'llâhu Teâlâ rûhahû}

Irâk meşâyihinin mütekaddimlerindendir. Harâbelerde sâkin olur idi. Kimseye karışmaz, kimse ile ihtilât etmez, kimseden bir şey almazdı. Taâm ettiğini bir kimse görmemiştir.

\section{Ebü'l-Abbâs b. 'Atâ Kuddise sirruhû}

Cenâb-1 Abbâs, Bağdâd meşâyihinin ulemâsından, sûfîlerinin zarîflerindendir. Sözleri pek parlak idi. Zebânı gâyet fasîh, meânî-i Kur'ân'da sâhib-i tasnîf idi.

309 (M. 922) senesinde mâh-1 Zi'l-ka‘dede terk-i dağdağa-i hayât eylemiştir. İbn-i Atâ'ya sordular ki; "Tâatlerin efdali nedir?" "Sûret-i dâimede Hak Teâlâ’yı mülâhaza eylemek, hâtırından çıkarmamaktır" buyurdu.

\section{[12]}

\section{Ebû Bekr er-Râzî Kaddesa'llâhu rûhahû}

Müteverri' ve müctehid bir zât-1 a'le'd-derecât idi. Meşâyih içinde kendisinden gözü yaşlı kimse görülmemiştir. Her mürîd ve mübtedî onu gördükleri vakit esîr ü giriftârı olurlardı. İbâdetinin, giryesinin, sabırsızlığının, hirkatinin ve semâ‘da 1ztırâbının kesretinden nâşî ibtidâ-1 kârında sefer edip Mekke-i Mükerreme'ye azm-i râh ile meşâyıh-1 sûfiyye ile mülâkât etti. Bir yıl kadar o mahall-i mübârekte mücâvir oldu. 


\section{Ebü'l-Kâsım er-Râzî Kaddesa'llâhu rûhahû}

İsm-i âlîleri Ca'fer b. Ahmed b. Muhammed'dir. Nîşâbûr sekenesinden idi. Çok mâla mâlik idi. Cümlesini bezl ederdi. Âkıbet dervîş olup dünyâdan gitti. Kendi şeyhlerinden birkaçı demişlerdir ki; "Ebü'l-Kâsım'da dört nesne cem“ olmuştu ki, kimsede yok idi: Cemâl, mâl, sehâvet, zühd ü kemâl”.

Bir gün sûfîler ile bir dâvete hâzır olmuş, cem'iyette bulunmuş idi. Ca'fer-i Huldî hazretleri dahi o mecliste bulunmuştu. Sofra başına oturduğu hâlde taâma el sunmadığını [13] hâzirûn görünce muvâfakât etmesini, taâm eylemesini söylediler. "Sâimim" dedi. Huldî-i müşârün-ileyh "Eğer orucunun sevâbı sence kardaşlarının ibtihâcından, şâdîliğinden sevgili ise savmını açma!" buyurdu. Cenâb-1 Kâsım ol sâatte orucu bozarak taâma başladı. Hicret'in 378'inde (M. 1085) târik-i libâs-1 hayât, lâbis-i câme-i memât olmuştur.

Ebû Abdullâh es-Sencerî Kaddesa'llâhu sirrehu'l-azîz

Tabaka-i sâniyedendir. Horasan meşâyihinin ulularından idi. Derece-i sehâsı nihâyete varmış, bezûl, sâhib-i himmet, ehl-i mürüvvet idi. Demiş̧ir ki; "Velîlerin alâmeti üçtür: Şunlardır ki; rif'atte iken tevâzu', kudrette iken dünyâdan perhîz, kuvveti varken insâf etmek." 47 Ve yine demiştir ki: "Her vâiz ki onun meclisinde ganîler fakîr, fakîrler ganî olup kalkmayalar; o vâiz değildir. Mürîdlere ziyâde fâideli nesne Sâlihler ile sohbet etmek, onların ef'âl ve harekât ve ahlâk ve ahvâline iktidâ eylemektir. Ve Allah Teâlâ Hazretlerinin dostlarının kabirlerini ziyâret etmektir. [14] yârânının, fukarânın hizmetinde bulunmaktır." Kendisine sordular ki; "Niçin sûfîlerin resmi üzere hırka giymezsin!" "Münâfıklıktır" cevâbında bulundu.

Şeyh Hacı Halîfe el-Kastamonî Kuddise sirruhû

Mübârek ismi Abdullah b. Hâcı'dır. Seccâdenişîn-i irşâd, postnişîn-i sâhib-i i'tikâd idi. İlm ü ma'rifet ehli idi. Hulk ve tevâzu'da zamânında vahîd, ta'bîr-i vekâyi'de ferîd idi. Menba'-1 lutf u ihsân ve mâil-i vücûh-1 hisân idi. Bünyede cesîm, hilyede besîm idi. Zamânında merci-i ekâbir-i ulemâ ve mürebbî-i fukarâ vü fuzalâ idi.

Hazret-i Şeyh, Hicretin 894 senesinin (M. 1488) Cemâziye'l-Âhiresi nihâyetinde âzim-i gülistân-1 cennet olmuştur.

Şeyh Muhyiddîn Abdülkâdir el-Geylâni ${ }^{48}$ Kuddise sirruhu'l-âlî

Abdülkâdir-i Geylânî Hazretleri, mâder-i şefkat-küsterinden doğduğu zamân Şehr-i Ramazân-1 Şerîf idi.

47 Müellif tercümesini vermeden önce bu sözün Arapçasını vermiştir. 48 Metinde "el-Cîlî" şeklinde yazılmıştır. 
Süt emmedi. O gün Ramazân-1 Şerîfin ibtidâsı olduğunu [15] dahi kâffe-i nâs Hazret-i Şeyh-i müşârün-ileyhin bu hâl-i sâimânesinden istidlâl eylediler. Hicretin 471. sene-i mübârekesinde tevellüd eylemişlerdir.

Bir gün Cenâb-1 Abdülkâdir ilme meşgûl olmak ve Sâlihleri ziyâret etmek emeliyle Bağdad'a gitmekliği vâlide-i muhteremelerine hikâye ve bu bâbdaki müsâade-i mâderânenin şeref-vâki' olması niyâz ve istirhâmını ifâdelerine ilâve eylediler.

Vâlide-i mes'ûdeleri dahi izin verdiği ve pederlerinden kalan 80 Lira mîrâsından kırk adedini [40 adedini dîğer oğluna alıkoymuştu] giyeceği kaftânının koltuk altına diktiği gibi cemî'-i ahvâlde sâdıkâne hareket etmesini, sadâkatten ayrılmamasını emir ve tenbîh eylediler. Rızâ-yı mâderîye nâil olan Geylânî Hazretleri o günlerde Bağdâd'a giden cüz'î bir kâfileye arkadaş olarak tevcîh-i râh-1 azîmet eylediler.

Epeyce bir mesâfe kat edildikten sonra önlerine altmış atlı kimseler çıkarak kâfileye dist-i dirâz-1 sirkat ü cinâyet olmağa başladıkları hâlde hîçbiri Abdülkâdir Hazretlerine taarruz etmediler. Nâ-gâh içlerinden biri gelip müşârün-ileyhe hitâben "Ey fakîr! Senin nesnen var mıdır?" dedi. Cevâben 40 altunu [16] olduğunu söyledi. "Nerendedir!" suâline "Koltuğumun altında" mukâbelesiyle kaftânına dikilmiş olduğunu dahi ilâve-i kelâm eyledi. Sâil, bu sözleri istihzâ olarak telâkkî birle def' oldu. Bunu ta'kîben dîğeri gelerek o dahi bu cevâbları alınca kezâ istihzâya haml ile terk edip gitti.

Ba'dehû bu iki sâil, başları olan kimseye ifâde-i hâl eylediklerinde reîs-i kâfile olan şahıs Hazret-i Şeyhi taleb ile deminki suâl îrâd edildi. Alınan cevâb yine o cevâb idi. Reîs-i merkûmun verdiği emr üzerine kaftânı kesip mahfûz olan kırk aded altunu vaz'-1 meydân eylediler.

Sonra merkûm şu vechile bir suâlde bulundu: "Sana ne oldu ki, böyle i'tirâf ettin!" Cenâb-1 Abdülkâdir'in; "Vâlidem sıdk u sadâkatten ayrılmamaklığımı sûret-i kat'iyyede ahd ü emreyledi de onun için!" cevâb-1 savâb-1 hayret-bahşâsını işitir işitmez, mihter-i merkûm hüngür hüngür ağlamağa, maiyeti olan efrâd-ı sâire dahi bu bükâ-yı nedâmet-kârâneye iştirâk ile girye-bâr-1 teessür olmağa başladıkları gibi o sâatte o zamâna kadar ettikleri cinâyet ve hıyânete tevbe ve Şeyh-i müşârün-ileyhin bulunduğu kâfileden her ne aldılarsa derhâl iâde eylediler.

\section{[17]}

Vaktâ ki Abdülkâdir Hazretleri Hicret'in 488'inde Bağdâd-ı bihişt-âbâda muvâsalatla tahsîl-i ulûm ile eyyâm-güzâr olmağa ve kırâat-1 Kur'ân-1 Kerîm ile fikıh, hadîs, ulûm-1 edebiyyeye ettiği sa'yü ikdâm cehd ü ihtimâm ile az zamânda akrânına gâlib gelmeğe başladı. Emsâlinin mütehayyizânından 
ahâlî-i asrın mütemeyyizânından oldu. Hicret'in 521'inde (M. 1127) vâiz-i mecâlis oldu. Ve ba'dehû ârif-i ef'âl-i Samedânî ve vâkıf-1 esrâr-1 Sübhânî olmağa başladı.

Zâhir kerâmâtı, ahvâl ve makâmâtı âlî idi. Sâmiîni engüşt ber-dehân-1 tefekkür edecek, veleh-resân-1 ezhân ü tasavvur olacak daha pek çok hâlât-1 ihtirâm-gâyâtı vardır. 561 senesinde (M. 1165-66) vâsıl-ı rahmet-i Mevlâ ve dâhil-i sâye-i şecer-i Tûbâ olmuşlardır.

\section{Seyyid Ahmed b. Ebü'l-Hasan er-Rifâî Kaddesa'llâhu Teâlâ sirrehû}

Makâmât-1 aliyye ve ahvâl-i seniyye 1ssı, sâhibi idi. Hak celle ve 'alâ Hazretleri Cenâb-1 Rifâînin elinde pek çok havârik-1 niam izhâr buyurdu. Ve onun için a'yânı telkîb eyledi. Kendisinden [17] acâyib nesneler çok zâhir oldu. Ashâbının içinde "ceyyid" ve "reddâ" yani iyi ahlâklı ve fâsid kimseler var idi. Ba'zısı âteşler içine girer, yılanlarla mülâabe ederlerdi. Bunlar, Şeyh-i müşârün-ileyhin ma'rûf ve mahbûbu olanlardan ve ashâbının Sâlihlerinden değil idi.

Bir gün ashâbından iki kimse sahrâya gidip yekdîğeriyle hikâye ve ifâdeye başladılar.

Şu muhâvere de o esnâda vukû' buldu:

Biri; "Sana bu kadar müddet içinde Seyyid Ahmed'in mülâzemetinden ne hâsıl oldu?"

Dîğeri; "Sen her ne dilersen iste!"

-"Ey Seyyidim! Dilerim ki cehennemden âzâdlığımı mübeşşir bir nâme, şu sâatte âsümândan nâzil ola!"

-"Hak Teâlâ'nın fazl u keremi hesâbsızdır".

Bunlar bu vechile söyleşmekte, arz-1 efkârda devâm eylemektelerken nâgâh gökyüzünden bir beyâz kâğıt bunların arasına [19] indi. Baktılar ki, hîç yazı yok! Doğru Hazret-i Pîr-i muhteremin huzûr-1 feyz-nüşûruna gelerek keyfiyyeti bi'l-ifâde ol varakı takdîm eylediler. Hazret-i Rifâî -radiye anhü'l-Bârî- varak-1 mezkûra nazar eder etmez Hâlık-1 Lem-yezel'e secde-berşükrân u ubûdiyyet oldu. Bir müddet sonra secdeden başını kaldırınca mübârek ağızlarından şu kelimât-ı hamd-gâyât sâdır oldu: "Cenâb-1 Bârî Teâlâ'ya şükürler olsun ki; ashâbımın cehennemden âzâdlığını bana âhiretten evvel gösterdi." 49

Dediler ki; "Ey Pîr-i pâk-i'tikâd ve Şeyh-i sâhib-i irşâdımız, bu varak aktir."

49 Metinde önce duanın Arapçası verilmiştir. 
Cevâben; "Kudret eli kara ile yazmaz; bu varak-1 mübârek nûr ile yazılmıştır." buyurdu. ${ }^{50}$

Hazret-i Seyyid Ahmed kuddise sirru-hu'l-ahad, ibâdete kemâl-i iştigâli olduğuyla berâber latîf şiirler tertîb, tanzîm ederdi. Şu şiirin -esâsen- şâir ve nâzımı müşârün-ileyhtir:

[20]

\section{Şiir ${ }^{51}$}

Kararsa geceler cânâ olup zikrinle dil hayrân

Kulur tâ subha dek yanup ciğerden ney gibi efgân

Durup ebr-i gam o semtten belâlar yağdırır her dem

Çıkup bahr-i dem altımdan gayyâlar kaynatır ${ }^{52}$ her ân

Üsârâ-yı gam u mihnet halâs oldukda ser cümle

Niçin bu ben giriftârı koyalar âciz ü nâlân

Ne katledüp beni korlar ki olam bir nefes râhat

Ne minnet eyleyüp âzâd ederler rûz u şeb ey cân.

Hicret'in 578. senesi (M. 1182) Cumâde'l-ûlâsının yirmi ikinci pencşenbe günü bi'l-irtihâl Cum'a gecesi azm-i nüzhet-serâ-yı cinân etmiş ve Cuma günü vedîa-i hâk-i gufrân edilmiştir.

\section{[21]}

Şeyh Muhyiddîn Muhammed b. Alî b. Muhammed el-Arabî Kuddise sirruhu'l-âlî

Şeyh-i müşârün-ileyh vahdet-i vücûda kâil olanların kıdvesidir. Kendilerine ulemâ ve fukahâ-i zâhireden çok kimse ta'n etmiş, fukahâ ve cemâat-i sûfiyyeden az kimse ta'zîm eylemiştir. Zât ü şânını tebcîl edenler hakkıyla tevkîr etmişler ve kelâmını medheylemişlerdir. Muhyiddîn-i Arabî Hazretlerinin latîf, garîb eş‘âr-1 âbdârı, nâdir, acîb ahbâr-1 veleh-âsârı vardır. Musannefâtı pek çoktur. Meşâyıh-ı Bağdâd'ın kibârından idi. Hakk-1 âlî-i reşâdetlerinde bu kitâbın me'hazı olan Nefehâtül-Üns'te pek çok tafsîlât verilmiş ve ona bile az nazar ile bakıldığı mütâlaât-ı muharrere hitâmından anlaşılmıştır.

Cenâb-1 Muhyiddîn, Hicret'in 560. senesi Ramazân-1 Şerîfi on yedisinde (M. 28 Temmuz 1165) Endülüs bilâdından Mürsiye'de tevellüd, 638 sene-

$50 \mathrm{Bu}$ tür ifadelerin söz konusu zâtlara duyulan güçlü sevgiden kaynaklandığını, bunun dışında bir anlam ifade etmediğini vurgulamalıyız.

51 Arabî olarak nazmetmişler ise de tercüme edilerek nakledilmiştir. (Müellifin dipnotu)

52 Renc ve eleme dûçâr eder demektir. (Müellifin dipnotu) 
si (M. 1240) Rebîü'l-âhirinin 22. Cuma gecesi Dımaşk'ta rıhlet eylemiştir ki, bu sûretle ömr-i mübârekleri 78 sene devâm eylemiştir.

\section{[22]}

Şemseddîn Muhammed Hâfız eş-Şîrâzî -Kaddesa'llâhu Teâlâ sirrehû

Müşârün-ileyh lisânü’l-gayb ve tercümân-1 esrârdır. Nice esrâr-1 gaybiyyeyi, meânî-i hakîkiyyeyi sûret kisvetinde ve mecâz libâsında göstermiştir. Dîvân'ı hakkında silsile-i hvâcegân azîzlerinden biri "Dîvân-1 Hâfız'dan mahbûb dîvân yoktur." buyurmuştur. Eş'âr-1 âbdârı ol derece meşhûrdur ki, beyâna ihtiyaç yoktur. Şîrâzî-i müşârün-ileyh Hâfız Muhammed -Aleyhi rahmeti Rabbi-hi'l-Ahad-'in "Her bir beyti bir humhâne-i aşk u hâlettir. Ve bir bezmgâh-1 zevk-1 ma'rifettir ki, cür'asından ukûl-i âlemiyân âşüfte ve neşvesinden efkâr-1 âdemiyân firîftedir. Siyt-i fezâili vü hasâili elfâz-1 nâdire gibi zemîne münteşir olmuş"tur.

Hicret'in 792'sinde (M. 1390) rûh-1 pür-fütûhu hadîka-i kemâl-i cihândan ravza-i irfân-1 cinâna uçmuştur.

\section{Mevlânâ Zahîrüddîn Halvetî Kaddesa'llâhu rûhahû}

Bu zât-1 şerîf, ulûm-1 zâhiriyyeyi vü bâtıniyyeyi câmi idi. [23] Hakk-1 mübârekinde Mevlânâ Zeynüddîn Hazretleri "Tâs-1 felek altında Zahîrüddîn gibi kimse görmedim." buyurmuşlardır ki; bu sözleriyle müşârün-ileyhin ulvî derecât bir zât-ı memdûhu's-sıfât olduğunu anlatmışlardır. Fahr-i Âlem (Salla'llâhu aleyhi ve selem) Efendimiz Hazretleri Şeyh-i müşârün-ileyhe bir gece âlem-i ma'nâda “Zahîrüddîn, Kur'ân'ı benden oku!" buyurmuşlardır. Ol dahi şeref-sâdır olan bu emr-i peygamberî üzerine Zât-1 Hazret-i Risâletpenâhîlerinden taallüm eylemiştir. Hazret-i Zahîrüddîn her ne vakit ki erbaîne oturur idi, bu zamânlarda buğdayla kaynamış su ile her on günde bir def'a olmak üzere dört kere iftâr ederdi. Hicret'in 800. senesinde (M. 1397) âlem-i ebedîye rihlet eylemiştir.

Mevlânâ Câmî-Kuddise sirru-hu's-sâmî-

İsm-i mübârekleri Abdurrahmân, peder-i bâbâ-menziletlerinin adı Ahmed'dir. Câmî tahallüs ederlerdi. Bu tahallüsün sebebini şu [24] kit'a-i âbdâr ile beyân buyurmuşlardır:

Mevlidem Câm der şemme-i kalemem

Cür'a-i câm-ı şeyhü'l-islâmîst

Zeyn-i sebeb der cerîde-i eş'âr

Bedr-i ma'nâ tehallusem Câmîst. ${ }^{53}$

53 "Doğum yerim Câm şehridir. Kalemimden (sadır olan) az bir şey Şeyhülislâmın kadehinden bir yudumdur. Sebebin süsü şiir derlememin içinde mânâ dolunayıdır ve mahlasım Câmî̀dir." 
Vefâtına yakın şu şi'rri bihteri söylemişlerdi:

Câmî ki bûd mâyil-i cennet mukîm şüd

Fîravza-i mükerreme-i "Arzuhe's-semâ"

Kilk-i kazâ nûşet revân-ber der-i bihişt.

Târîh-i dey "Ve men dehalehû âminen". ${ }^{54}$

Müşârün-ileyh meşâyih-i izâmdan nice kimse ile musâhabet eylemiştir. Kendisi fuzalâ-yı dehrden ve ulemâ-i asrdan idi. Zamânının ferîdi ve fünûn-u maârifin vahîdi idi. Âvâze-i maârifi etrâf-1 âleme o derece münteşir olmuş idi ki, Sultân-1 Rûm, surreler ile sılalar gönderip kudûm-i şerîflerini tevakku' ederlerdi.

Sâhibü'l-Hind Hvâce Cihân ile latîf mürâsele ve muhâvereleri vardır. Letâfet ü şive vü üslûb u ifâde bunların münşeâtında görünmüştür. Hazret-i Câmî manzûm, mensûr resâil-i müteaddideye sâhibdir. Üç aded -mükemmel hurûf üzerine- Dîvân'ı vardır ki el-yevm makbûl-i urefâ ve üdebâ, mahbûb-i zürefâ [25] ve şuarâdır. Şuarâ-yı eslâfın kasîdelerine ayrı ayrı cevâblar vermiştir.

Tarîk-1 nazmda üslûb-1 acîbi ve tarz u tavr-1 garîbi vardır. Belâğat ve fesâhati müsellem, ilm-i hakîkat ve esrâr-1 tarîkatte cidden makbûl, hakîkaten memdûh müellefât-1 güzîde-i kesîresi ma'lûm-1 âlemdir. Fünûn-1 muammâ ve kâfiyede ve arûzda ve sanâyi-i şi'r ile ilm-i hesâbda behre-i kâmilesi var idi. Kur'ân-1 Azîmü'ş-şân'ın evâiline Arabî tefsîr yazmış, Kâfiye'yi bi-tamâmihâ şerh eylemiştir. Fezâil ve mehâsin-i ahlâka mâlik bir zât-i vâcibü'l-hürme idi. Sâhibü'l-i'tibâr bir hvâce-i zî̀-iktidâr ve el-hak üstâd-ı nâdire-kâr idi.

Hicret'in 898'inde (M. 1492) mürğ-i rûh-1 pür-fütûhları tâir-i ravza-i firdevsü'l-berîn olmuştur.

Kabr-i müteberrikleri Herât'tadır.

\section{Şeyh Ebû Abdullah es-Savmaî Kaddesa'llâhu rûhahû}

Geylân meşâyihinin ulularından ve zâhidlerinin reîslerinden idi. Âlî ahvâli ve zâhir kerâmâtı var idi. Acem meşâyıhının da efdal ve a'zamları sırasına geçmiş idi. Müstecâbü'd-da've idi. Hak celle ve alâ hazretlerinden ne dilerse ihsân eder idi. Bir vakit gazab eyledi idi; Hak Teâlâ kendisinden ötürü hemân intikâm aldı. Müşârün-ileyh her ne olacağını haber verse vâki' olurdu.

54 "Câmî cennete yöneldi ve orada mukim oldu; "Genişliği gökler kadar..." âyetinde geçen en keremli bahçededir o. Sen cennet içinde yürüyüp giden kaza kamışından çek. (Ölüm tarihi) kış mevsiminde / güneş yılının onuncu ayında (Ekim) "Oraya giren emniyette olur" (Âl-i İmrân 3/ 97) âyetindedir." Şiirde iktibas edilen ilk ayetin tamamını tercümesi şöyledir: "Rabbinizin bağışına ve takvâ sahipleri için hazırlanmıs olup genișliği gökler ve yerler kadar olan cennete koşun." (Âl-i İmrân 3/131). Yalnız söz konusu iktibas, bu âyette "Arzuhe's-semâvât" şeklinde geçmektedir. İkinci âyette ise "âminen" kelimesinden önce "kâne" kelimesi vardır.Âyet ebced hesâbıyla Câmî̀nin ölüm tarihini vermektedir: H. 898/M. 1492. 
Ashâbından bir cemâat, ticâret kasdiyle Semerkand'e gitmişlerdi. Ora kurbünde bir sürü atlı kimseler bunları tehdîd ve mâllarını yağma etmeğe başlayacakları esnâda Hazret-i Şeyh; "Ey süvârîler, uzak olun bizim içimizden!" hitâb-1 hâifânesiyle cümlesini darmadağın etti. Bir hâlde ki, cümlesi atlardan düşerek pek çoğu dağlara kaçtı. Bir kısmı da dereler arasına karıştılar. [27] İki kişi bir yere gelmeğe kâdir olamadı. Ashâb da o hâinlerin şerrinden bu vechile kurtuldular.

Yazıcızâde Ahmed ve Muhammed Çelebiler Kaddesa'llâhu Teâlâ ervâhahümâ ve esrârehümấ5

Müşârün-ileyhimâ kurb-i asrımızda iştihâr eden azîzândandır. Bu iki zât1 kardaş-1 mübârekten Ahmed Çelebi Envârü'l-Âşıkîn nâm kitâb-1 müşgînnikâbın sâhibidir. Bu zât-1 a'le'd-derecâta "Ahmed-i Bîcân" derler. Muhammed Çelebi ise kitâb-1 âlî-i Muhammediyye'nin sâhibidir. İkisi dahi yek-dîğerine rekâbet ve müsâbakat edercesine sâhib-i fazl u kemâl ve sülûkunu itmâm etmiş zâteyn-i muhteremeyn-i hamîdü'l-hisâldir. Gelibolu'da medfûndurlar. Kerâmât ve fezâilleri müellefât-1 aliyye-i kâinât-pesendânelelerinden ma'lûmdur. Hele kitâb-1 müstetâb-1 Muhammediyye, âzâde-i beyân olduğu [28] üzere Türkî lisânın faslü'l-hitâbı, erbâb-ı mevâizin kemâl-i sıhhat üzerine güzel bir kitâbıdır.

\section{Yûnus Emre Kaddesa'llâhu rûhahû}

Rûm'da iştihâr edenlerdendir. Meşhûr ve ma'rûf sözleri vardır. Cümlesi makbûl-i tavâiftir. Serâser esrâr-1 tevhîd ve etvâr-1 tefrîddir ve rumûz u işârettir. Dîvân'ında "Çıktım erik dalına anda yedim üzümü / Bostan ıssı kakıdı der ne yersin kozumu" ile başlar gâyet latîf bir şi'ri vardır. Şeyhi olan Tapduk Emre'ye nice seneler arkasında odun götürdü. Taşıdığı yüz binlerce odundan bir dâne eğri görülmedi.

Şeyhi -Kaddesâllâhu sirrehû-; "Yûnus, hîç bu odunların içinde bir eğri ağaç göremiyorum!" deyince; "Şeyhim, sultânım! Bu kapudan eğri sı̆̆maz." cevâbıyla kendisinin ne derece ehl-i kemâl olduğunu göstermiştir.

[29] Hazret-i Yûnus, Kütahya'da vaz'-1 hâk-i gufrân ve vedîa-i vâdî-i hâmûşân kılınmıştır. ${ }^{56}$

55 Metinde "ervâhehû ve esrârehû" yazılmışsa da "ervâhehümâ ve esrârehümâ" şeklinde düzelttik. 56 Yunus Emre'nin kabri konusunu Mustafa Tatcı geniş bir biçimde araştırmıştır. Verdiği yer adları arasında ise Kütahya'ya rastlanmaz. Dolaysıyla Sâlih Sâim'in verdiği bu bilginin sıhhati tartışmalıdır. Bkz. Tatcı, Yunus Emre Divanı I: İnceleme, Kültür Bakanlığı Yayınları, Ankara, 1990, s. $34-43$. 
Hâcı Bektaş-ı Velî Kaddesa'llâhu Teâlâ sirrehu'l-'âlî

Müşârün-bi'l-benân olanlardan biri de Hazret-i Bektâş-1 Velî'dir. Türkmen vilâyetinde medfûndur. Sâhib-i velâyet ü kerâmet idi. Türbe-i şerîfe ve münîfeleri ziyâretgâh-1 hâss u 'âmm ve mutâf-1 âlemiyândır. Zât-1 şerîfine mensûbiyyetle ekseriyâ ribka-i İslâm'ı boyunlarından ihrâc edip ibâhat otlağında halî́'u'l-'izâr gezenlere zât-1 mübâreki ile fezâil ve ulüvv-i ahlâk sâhibleri o kimselere mensûb demezler.

Son. 